\section{AiCS}

How to cite this article: Simões et al. Analysis of vaccine losses by temperature changes in a Health Region from Minas Gerais State, Brazil. ABCS Health Sci. 2020,45:1261. https://doi.org/10.7322/ abcshs.45.2020.1261

Received: Mar 25, 2019

Revised: May 27, 2019

Approved: Jul 01, 2019

Corresponding author: Heuler Souza

Andrade - Universidade do Estado de Minas

Gerais - Avenida Paraná, 3001 -

Jardim Belvedere - CEP: 35501-170 -

Divinópolis (MG), Brasil -

E-mail: heuler.andrade@uemg.br

Declaration of interests: nothing to declare

This is an open access article distributed under the terms of the Creative Commons Attribution License

(C) 2020 Simões et al.

\title{
Analysis of vaccine losses by temperature changes in a Health Region from Minas Gerais State, Brazil
}

\author{
Naiara Cristina Silva Simões ${ }^{1}$, Isabela Flávia dos Santos ${ }^{1}$, Valéria Conceição Oliveira ${ }^{2}$ \\ Eliete Albano de Azevedo Guimarães², Heuler Souza Andrade ${ }^{1}$ \\ ${ }^{1}$ Universidade do Estado de Minas Gerais (UEMG) - Divinópolis (MG), Brasil. \\ 'Universidade Federal de São João Del Rei (UFSJ) - Divinópolis (MG), Brasil.
}

\begin{abstract}
Introduction: Immunobiologicals are of great importance for the prevention and eradication of diseases. However, the lack of maintenance of the cold chain generates several problems related to losses of these substances, burdening an important amount of public resources. Objective: To analyze vaccine losses in a Health Region (Região Ampliada de Saúde Oeste) of Minas Gerais State in Brazil. Methods: This is a descriptive study, based on secondary data obtained through forms used by the regional health agency (Superintendência Regional de Saúde, SRS), to register losses of immunobiologicals due to temperature changes. Forms from February 2016 through January 2018 were analyzed. The data was organized and validated by double typing. Results: Vaccine losses were caused by lack of electrical energy $(40.83 \%)$, followed by equipment failure $(36.67 \%)$, and professional error $(10 \%)$. As a consequence, 17,229 bottles of vaccines $(65.78 \%)$ were discarded, corresponding to 111,145 doses. The financial loss was R $\$ 604,340.31$. Conclusion: Losses of vaccines due to temperature changes were relevant in the studied region, damaging the budget for the local health network. Therefore, it is suggested that measures to minimize these losses should be adopted.
\end{abstract}

Keywords: vaccines; storage of substances; products and materials; biological products; refrigeration.

\section{INTRODUCTION}

The National Immunization Program (Programa Nacional de Imunizações - PNI) was created in 1973 by the Ministry of Health (MS), using basic vaccination strategies, which were developed to contribute to the control and eradication of vaccine-preventable diseases, cooperating with the maintenance of population health ${ }^{1}$.

In order to maintain their immunogenicity and efficacy, vaccines need to be kept at controlled and ideal temperatures, until the time of use ${ }^{2}$. The PNI has rules that must be strictly respected for the proper conservation of these substances. Such standards provide for the adequacy of vaccine rooms, which concerns lighting, organization, cleaning, provision of necessary materials and adequate training of professionals who will handle vaccines or work in vaccination rooms ${ }^{3}$. This training ranges from the 
correct techniques to perform the procedures to knowledge about the Cold Chains (Rede de Frio - RF and Cadeia de Frio - CF) ${ }^{4}$.

The RF is a technical-administrative system to sustain $\mathrm{CF}$, through normative actions, planning, evaluation and financing ${ }^{4}$. $\mathrm{CF}$ is the management system that involves the storage, conservation, handling, distribution and transport of immunobiologicals used in immunization programs, with the ultimate goal of ensuring the support of their immunogenic characteristics. Maintaining the integrity of the CF is a major challenge that demands complete integration between the different levels, requiring responsibility and commitment from the immunization services and MS teams $\mathrm{s}^{5,6}$.

The lack of CF maintenance generates several problems related to significant losses of immunobiologicals, these losses being technical and physical. The technical loss can be considered justifiable, as, for example, after the opening of a multidose bottle, there may not be enough population for vaccination, and then the time limit for its use occurs. The physical or preventable loss happens due to handling errors, conservation problems, loss of validity, among others, which can be caused by the incapacity of the professionals involved in the vaccination and maintenance process of $\mathrm{CF}^{1,7}$.

Although there are rules for the proper packaging and conservation of vaccines, and also for monitoring losses, there are several obstacles in health units, which can interfere in maintaining the quality of immunobiologicals, causing suspicion or even loss. Problems such as the lack of adequate immunobiological refrigeration equipment, the packaging of other products in this equipment, the absence of a preventive/corrective maintenance program, the absence or incorrect use of thermometers indicating maximum and minimum temperatures, the exposure of vaccines to temperatures inadequate, incorrect temperature verification, among others, directly interfere with the pharmacological characteristics of immunobiologicals, changing their effectiveness ${ }^{3,8}$.

The professionals' lack of knowledge about CF norms, regarding the packaging, handling and transport of vaccines is another problem that directly interferes with the immunobiological offered to the population. The inadequate knowledge of professionals in the vaccination rooms and the little understanding of the damage caused by temperature changes, contribute to the fragility of the maintenance of RF and are related, in most cases, to the inadequate conservation of immunobiologicals and their physical loss ${ }^{9,10}$.

As there are few studies related to the evaluation of the organizational and operational aspects of immunobiologicals, especially when it comes to maintaining $\mathrm{CF}$, it is necessary to know the problems related to vaccine losses, especially preventable losses. Although several advances have been made in the health system in Brazil, there is a gap in management concerning the structural and organizational aspects of vaccination rooms, which reinforces the importance of systematic supervision by the higher hierarchical levels of the health system ${ }^{11}$.

Considering the importance of immunization in the process of preventing diseases and improving the health of the population and the fact that vaccine losses burden an important amount of public resources, it is relevant to analyze this problem in order to know the determinants of the problem and suggest measures that can act directly in preventing these losses.

Thus, the objective of the study was to analyze the vaccine losses in a Health Region (Região Ampliada de Saúde Oeste) of Minas Gerais, Brazil, due to temperature changes, describing the main determinants of the losses of immunobiologicals, and identifying the preventable causes among vaccine losses.

\section{METHODS}

This is a descriptive study, based on secondary data, conducted in a Health Region (Região Ampliada de Saúde Oeste) of Minas Gerais, Brazil, in 2018.

The state of Minas Gerais is divided into 13 Health Regions, which are: Sul, Centro Sul, Centro, Jequitinhonha, Oeste, Leste, Sudeste, Norte, Noroeste, Leste do Sul, Nordeste, Triângulo do Sul, e Triângulo do Norte. The Região Ampliada de Saúde Oeste is divided into six microregions and consists of 54 municipalities, where there are 370 vaccination rooms, managed, at the regional level, by a regulation and distribution center, located in the Regional Health Superintendence (Superintendência Regional de Saúde - SRS) $)^{12}$. All municipalities in the studied region were included in the study.

The data were obtained using the forms used by SRS, to assess losses of immunobiologicals due to temperature changes. These forms are filled out by those responsible for the municipal vaccination rooms when there is a change in the temperature of the refrigeration equipment and sent to the SRS. At SRS, forms are scanned and filed. Subsequently, they are sent to the Secretary of State for Health (Secretária de Estado de Saúde - SES), where there is an official response through memos, regarding the measures to be taken concerning immunobiologicals under suspicion. All forms produced in the period from February 2016, which corresponds to the beginning of the filing, until January 2018, which was the last month available in the collection period, were eligible for the study. However, when searching the files, not all forms were found, making verification with memos difficult.

Thus, the following variables were analyzed: year of occurrence, municipality of occurrence, type of refrigeration equipment, types of gauges existing at the location of the occurrence, reason for the occurrence, temperature data at the time when a possible equipment failure was detected (refrigerator), the description of the accident and the measures taken in relation to the vaccines, the value of the loss with the unused vaccines, and the number 
of doses missed. The monetary values of the losses were considered according to the year 2018 and provided by the Regional Technical Reference in immunization through the SUS Strategic Inputs Information System (Sistema de Informação de Insumos Estratégicos do SUS - SIES-DATASUS). For reasons of confidentiality, the municipalities were identified by codes (e.g. M1), in order of the highest occurrence of suspected losses.

Data collection took place between March and May 2018, after consolidating the data for the year 2017 and January 2018. The data were organized and validated by double entry, in the Microsoft Excel 2016 software. The analysis was performed descriptively.

Although the data searched was secondary, it was not in the public domain. Therefore, the study was submitted to the consent of the SRS and approval by the Comitê de Ética em Pesquisa da UEMG/Divinópolis and approved under opinion No. 2,413,213.

\section{RESULTS}

During the study period, 138 forms were produced, but not all were located. Only 120 (87\%) were found. The year with more occurrences (60, corresponding to 50\%) was 2016. Among the 54 municipalities belonging to the Health Region, there were occurrences in 27 of them. The municipalities that most notified were M1 with 28 occurrences (23.3\%) and M2 with $22(18.3 \%)$ (Table 1). The municipalities that had less than five occurrences were classified as "Others" in order to optimize the table.

Table 2 shows that 64 (53.3\%) vaccination rooms where there were occurrences had domestic refrigerators. Regarding the types of gauges existing at the place of occurrence, the moment thermometer, maximum and minimum digital is the most used, with a total of $88(73.33 \%)$ gauges.

The data in notification show that the maximum temperature of vaccine storage reached levels above the ideal temperature in 97 occurrences $(80.8 \%)$. Regarding the minimum temperatures,

Table 1: Characteristics of Forms for the Evaluation of Immunobiologicals under suspicion in the Health Region (Região Ampliada de Saúde Oeste) of Minas Gerais, 2016-2018.

\begin{tabular}{|l|c|c|}
\hline Characteristics & $\mathbf{n}$ & $\%$ \\
\hline \begin{tabular}{|l|} 
Forms \\
Located
\end{tabular} & 120 & 87.0 \\
\hline Not located & 18 & 13.0 \\
\hline Year & & \\
\hline 2016 & 60 & 50.0 \\
\hline 2017 & 57 & 47.5 \\
\hline 2018 & 3 & 2.5 \\
\hline Municipality & & \\
\hline M1 & 28 & 23.3 \\
\hline M2 & 22 & 18.3 \\
\hline M3 & 15 & 12.5 \\
\hline M4 & 5 & 4.2 \\
\hline Others & 50 & 41.7 \\
\hline
\end{tabular}

27 occurrences $(22.50 \%)$ recorded temperature below the ideal. With regard to the temperature of the moment, there were $66(55.00 \%)$ occurrences in which the temperature was outside the range considered ideal, as described in Table 3.

Among the accidents that caused the occurrences, the refrigerator's lack of capacity to maintain the ideal temperature was responsible for $41(34.17 \%)$ of the equipment failures. Regarding the professionals' mistakes, the thermal box left open was mentioned $2(1.67 \%)$ times. In other problems, the lack of electricity in the municipality was described 49 (40.83\%) times (Table 4$)$.

Of the immunobiologicals placed under suspicion, 17,229 vials (65.78\%) were discarded, totaling 111,145 losses. The year with the highest number of losses was 2016, with 71,050 (63.93\%) doses. Consequently, it was the year with the highest financial value of losses, totaling R\$352,498.97 (58.35\%) (Table 5).

Table 2: Characterization of vaccination rooms where notifications occurred in the municipalities of the Health Region (Região Ampliada de Saúde Oeste) of Minas Gerais, 2016-2018.

\begin{tabular}{|l|c|c|}
\hline Characteristics & N & $\%$ \\
\hline $\begin{array}{l}\text { Types of refrigerators } \\
\text { Domestic refrigerator }\end{array}$ & 64 & 53.3 \\
\hline Refrigerated chamber & 26 & 21.7 \\
\hline Cold chamber - cold chain & 120 & 10.0 \\
\hline Cooler & 8 & 6.7 \\
\hline Cold chamber & 3 & 2.5 \\
\hline Cooler and cold room & 1 & 0.8 \\
\hline Not informed & 6 & 5.0 \\
\hline Types of gauges & & \\
\hline Digital thermometer & 88 & 73.3 \\
\hline Analog and digital thermometer & 24 & 20.0 \\
\hline Analog thermometer & 4 & 3.3 \\
\hline Digital and linear thermometer & 1 & 0.8 \\
\hline Linear and analog thermometer & 1 & 0.8 \\
\hline Not informed & 2 & 1.7 \\
\hline
\end{tabular}

Table 3: Temperature of the refrigeration equipment in the vaccination rooms, at the time the occurrences were recorded, in the municipalities of the Health Region (Região Ampliada de Saúde Oeste) of Minas Gerais, 2016-2018.

\begin{tabular}{|l|c|c|}
\hline \begin{tabular}{l} 
Temperature \\
\hline Maximum
\end{tabular} & N & $\%$ \\
\hline $\begin{array}{l}0.5^{\circ} \mathrm{C} \text { to } 1.9^{\circ} \mathrm{C} \\
+2.0^{\circ} \mathrm{C} \text { to }+8.0^{\circ} \mathrm{C}\end{array}$ & 3 & 2.5 \\
\hline More than $8.0^{\circ} \mathrm{C}$ & 16 & 13.3 \\
\hline Not informed & 97 & 80.8 \\
\hline Minimum & 4 & 3.3 \\
\hline$-1.0^{\circ} \mathrm{C}$ to $1.9^{\circ} \mathrm{C}$ & 27 & 22.5 \\
\hline$+2.0^{\circ} \mathrm{C}$ to $+8.0^{\circ} \mathrm{C}$ & 64 & 53.3 \\
\hline More than $8.0^{\circ} \mathrm{C}$ & 25 & 20.8 \\
\hline Not informed & 4 & 3.3 \\
\hline At the moment & & \\
\hline $0.0^{\circ} \mathrm{C}$ to $1.9^{\circ} \mathrm{C}$ & 12 & 10.0 \\
\hline$+2.0^{\circ} \mathrm{C}$ to $+8.0^{\circ} \mathrm{C}$ & 50 & 41.7 \\
\hline More than $8.0^{\circ} \mathrm{C}$ & 54 & 45.0 \\
\hline Not informed & 4 & 3.3 \\
\hline
\end{tabular}


The monetary values of certain special immunobiologicals and also, the values detailed by lost immunobiologicals, were not made available, preventing a real valuation of losses.

\section{DISCUSSION}

To maintain vaccine coverage, it is essential to ensure the safety of vaccines ${ }^{13}$. Although most of the losses were attributed to the lack of electricity, considerable losses were observed due to equipment failures and professional error. These two events could have

Table 4: Description of the occurrence and of the immunobiologicals under suspicion of the Health Region (Região Ampliada de Saúde Oeste) of Minas Gerais, 2016-2018.

\begin{tabular}{|c|c|c|}
\hline Description of the accident & $\mathbf{N}$ & $\%$ \\
\hline \multicolumn{3}{|l|}{ Equipment failure } \\
\hline $\begin{array}{l}\text { Refrigerator was not maintaining } \\
\text { the ideal temperature }\end{array}$ & 41 & 34.2 \\
\hline $\begin{array}{l}\text { Refrigerator was connected to the nobreak, } \\
\text { which was turned off, changing the temperature. }\end{array}$ & 2 & 1.7 \\
\hline $\begin{array}{l}\text { Digital thermometer failure, divergence of } \\
\text { values was found with the analog thermometer. }\end{array}$ & 1 & 0.8 \\
\hline \multicolumn{3}{|l|}{ Professional error } \\
\hline The unit's thermal box was left open & 2 & 1.7 \\
\hline Inadequately closed cooler & 1 & 0.8 \\
\hline Refrigerator door left open & 1 & 0.8 \\
\hline Failure to check the temperature of the cooler & 1 & 0.8 \\
\hline Vaccines left out of the fridge & 1 & 0.8 \\
\hline Transport failure of immunobiologicals & 1 & 0.8 \\
\hline $\begin{array}{l}\text { Suspected vaccines discarded } \\
\text { without consulting regional }\end{array}$ & 1 & 0.8 \\
\hline Others & 4 & 3.3 \\
\hline \multicolumn{3}{|l|}{ Other occurrences } \\
\hline Lack of electricity in the municipality & 49 & 40.8 \\
\hline Vandalism & 9 & 7.5 \\
\hline $\begin{array}{l}\text { Inadequate number of coolers to } \\
\text { store vaccines in the refrigerator }\end{array}$ & 1 & 0.8 \\
\hline Not informed & 5 & 4.17 \\
\hline
\end{tabular}

Table 5: Outcome of immunobiologicals under suspicion of vaccines in the Health Region (Região Ampliada de Saúde Oeste) of Minas Gerais, 2016-2018.

\begin{tabular}{|l|c|c|}
\hline \multirow{2}{*}{\begin{tabular}{|c|}
$|c|$ \\
\cline { 2 - 3 }
\end{tabular}} & Outcome \\
\hline Immunobiologicals under suspicion & & $\%$ \\
\hline Number of unused bottles & 17229 & 65.8 \\
\hline Nomber of bottles used & 8961 & 34.2 \\
\hline Losses & 26190 & 100.0 \\
\hline 2016 & & \\
\hline 2017 & 71,050 & 63.9 \\
\hline 2018 & 40,213 & 35.7 \\
\hline Total & 402 & 0.4 \\
\hline & 111,145 & 100.0 \\
\hline 2016 & Value of losses* \\
\hline 2017 & R\$ (Brazilian coin) & $\%$ \\
\hline 2018 & $352,498.97$ & 58.3 \\
\hline Total & $246,883.03$ & 40.9 \\
\hline *Source: SIES-DATASUS & $4,958.31$ & 0.8 \\
\hline
\end{tabular}

been avoided had there been greater attention and monitoring of equipment and temperatures.

Regarding human failures, experts emphasize the constant need for permanent education for professionals who work in vaccination rooms, since it was evident the direct influence of this professional gap leading to the loss of vaccines ${ }^{14,15}$. Thus, nurses should have greater participation in vaccination rooms, to manage and supervise the adequate conservation of the immunobiologicals that will be administered, and to evaluate the performance of the nursing team, to have more participatory and targeted monitoring for the improvement of the team, aiming at the quality of assistance.

Only half of the municipalities in the region reported changes in the temperature of immunobiologicals during the period studied. This data needs to be assessed with caution and presupposes whether underreporting of cases is occurring in the region. It becomes necessary to pay attention to guidelines on the importance of placing vaccines that have changed under suspicion, so as not to pose risks to the health of the population ${ }^{16}$.

Permanent education must be designed to improve the technical quality of professionals so that they endorse the cold chain of vaccine conservation and thus the quality of immunobiologicals offered to the population. Studies show that the professionals themselves note the need for a more effective update on the PNI, the RF and the $\mathrm{CF}$, noting that the Basic Units are not carrying out such education, leaving only the health departments responsible for such responsibility. Although the equipment made available by the State is being modernized and becoming more effective, without a qualified professional, such equipment will not be able to ensure the quality of immunobiologicals ${ }^{13,15}$.

The predominance of the domestic refrigerator among the most common equipment is similar to another study, which was carried out in 253 vaccination rooms, where only two had a special refrigerator (Refrigerated Chamber) and the rest had the domestic type refrigerator ${ }^{17}$. Although they are widely used for the storage of immunobiologicals, and despite providing ease of acquisition and low cost, domestic refrigerators are no longer recommended by international bodies or by the MS for this practice, as they do not offer safety and quality in relation to the maintenance of ideal temperature for the conservation of these substances. Vaccination rooms that use these types of refrigerators should require replacement by refrigerated chambers ${ }^{18,19}$.

A positive point in the records of vaccines under suspicion, is the availability of thermometers in the vaccination rooms, with more than five forms of gauges, which seem to fulfill the function properly. There was only one occurrence that pointed out problems with the existing gauges, which is opposed by another study, which states that many digital thermometers, or extension cables, that measure the current, maximum and minimum temperatures of vaccine rooms were apparently damaged ${ }^{20}$. 
It is understood, then, that such damage could influence the correct measurement of temperatures, which makes it important to emphasize that professionals should know the importance of using the maximum and minimum thermometer, and take the daily temperature reading. Standardization of gauging models by municipalities would facilitate this monitoring.

The temperature changes perceived in this study confirm the need for more modern equipment for vaccine rooms, seeking to implement an automated system, aiming to reduce errors related to changes in equipment temperatures and consequently the reduction of vaccine losses. A study emphasized that, even though the rooms record the temperatures of the refrigerators on the daily map, they were outside the values recommended by the $\mathrm{PNI}^{20}$. The data logger and the Electronic Refrigerator Recorder are examples of more modern equipment that could be used in vaccination rooms to correct the aforementioned problem, since they are digital data recorders that monitor the temperature automatically and more often than manual methods $s^{16,21,22}$.

In relation to vaccines placed under suspicion, most of them were due to equipment failure, which was not maintaining the ideal temperature. Immunobiologicals exposed to inappropriate equipment, which pose a risk of temperature changes, are constantly placed under suspicion. One of the causes of this problem is the option of many municipalities to carry out reparative maintenance instead of preventive maintenance, as evidenced in another study related to the quality of conservation and storage of immunobiologicals ${ }^{23}$.

In cases of temperature variations outside the ideal standard, it is recommended to immediately report what happened to the municipal and regional reference bodies, to fill out and send a specific form for the evaluation of immunobiologicals under suspicion and to keep the vaccines at temperatures between +2 and $+8^{\circ} \mathrm{C}$ until the final pronouncement ${ }^{4}$. Knowing this, a study showed that, of 18 Family Health Strategies (Estratégias de Saúde da Família - ESF) vaccination rooms, only $38.9 \%$ of technical supervising nurses perform the process mentioned above, given the problem of submitting to inappropriate temperatures of immunobiologicals ${ }^{3}$.

The financial loss to SUS with vaccines that were unusable in the period under study reinforces the need to evaluate the costs generated by avoidable losses, since this amount could be destined for investment in new technologies. Study points out some solutions, such as the manufacture of single-dose vaccines, the adoption of technologies that enable the use of less thermolabile vaccines and the training of staff to work effectively in vaccination rooms ${ }^{7}$.

With vaccines that were rendered useless, 111,145 doses were lost. As also found in a study in which the loss of immunobiologicals due to preventable causes was 3,437,552 doses ${ }^{1}$.
Such doses could be being used for the immunization of the population and reinforcing the prevention of diseases preventable by the basic vaccination schedule and some special ones available in the system.

A limiting factor of the study was the existence of records from the last three years only, since the previous ones were discarded without an informed reason. In addition, when data is shared between the involved bodies, some data relating to the number of vaccines placed under suspicion is lost.

With the realization of the study it can be identified that among the determining factors for the loss of immunobiologicals, what stood out the most was the lack of electricity in the city, which could be mitigated with the use of nobreaks in the refrigerators, as recommended by the $\mathrm{CF}$, or by sending smaller amounts of immunobiologicals to the municipalities most affected by this problem. The failure in the equipment also occupied a prominent place, which reinforces, according to the $\mathrm{CF}$, that the use of domestic refrigerators is not the most suitable for the storage of immunobiologicals. The analysis of the losses also showed that the thermometers are widely used, however the temperatures fluctuate well beyond the ideal temperature, making it possible to inquire about the discontinuity of the care of the nursing staff in the care of the vaccine rooms.

Although many studies highlight technical losses, this study shows that the index of physical losses from vaccines, due to temperature changes, in the studied region was relevant, which burden SUS, as the value could be used for other important purposes in prevention comorbidities. Among the factors already mentioned, it should be highlighted the non-preventive maintenance of the equipment, together with the professional's mistakes, which could have been avoided.

The importance of using and correctly filling out the Forms for the evaluation of immunobiologicals under suspicion also needs to be stressed for better monitoring of the PNI, and in order to ensure that the immunobiologicals that are offered to the population preserve their immunogenic capacity.

Therefore, it is suggested the adoption of some management behaviors of the Ministry of Health, together with the state and regional health, which can help in reducing these losses, such as the reevaluation of the calculation of the quotas for sending immunobiologicals, so that excess doses are sent. It is also necessary to analyze the question of the response time of the regional offices for the health units, in relation to vaccines placed under suspicion, to avoid possible losses due to validity, since this analysis must be taken as a priority.

However, it is hoped that this study can stimulate a process of reflection to health professionals about the importance of supervision, monitoring and evaluation of activities related to $\mathrm{CF}$, aiming to achieve greater effectiveness in the conservation and manipulation of immunobiologicals. 


\section{REFERENCES}

1. Oliveira VBCA, Caveião C, Crosewski F. Gerenciamento de enfermagem no controle de perdas evitáveis de imunobiológicos. Cogitare Enferm. 2014;19(4):679-86.

http://dx.doi.org/10.5380/ce.v19i4.36358

2. Raglione D, Bezerra GAM, Lopes MH, Nerger MLBR, Guimarães TC, Sartori AMC. Avaliação da rede de frio para conservação de vacinas em unidades básicas de saúde das regiões Sul e CentroOeste do município de São Paulo em 2011-2012. Epidemiol Serv Saude. 2016;25(1):65-74

http://dx.doi.org/10.5123/s1679-49742016000100007

3. Siqueira LG, Martins AMEBL, Versiani CMC, Almeida LAV, Oliveira CS, Nascimento JE, et al. Avaliação da organização e funcionamento das salas de vacina na Atenção Primária à Saúde em Montes Claros, Minas Gerais, 2015. Epidemiol Serv Saude. 2017;26(3):557-68

http://dx.doi.org/10.5123/s1679-49742017000300013

4. Brasil. Ministério da Saúde. Secretaria de Vigilância em Saúde. Departamento de Vigilância das Doenças Transmissíveis. Manual de rede de frio do Programa Nacional de Imunizações. 5 ed. Brasília: Ministério da Saúde, 2017

5. Silva PLN, Alves CR, Versiani CMC, Gonçalves RPF, Souto SGT, Santos CLS. Adequabilidade do setor vacinal das unidades básicas de saúde na perspectiva prática da enfermagem. Rev Enferm UFPE. 2014;8(10):3250-5.

http://dx.doi.org/10.5205/reuol.6039-55477-1-ED.0810201401

6. Deus SRM, Marques ADB, Teixeira JCL, Deus PRM, Moraes MEA, Macêdo DS. Estudo dos procedimentos quanto à conservação das vacinas do programa nacional de imunização. Rev Enferm UFPE. 2016;10(3):1038-46.

http://dx.doi.org/10.5205/reuol.8702-76273-4-SM.1003201613

7. Pereira DDS, Neves EB, Gemelli M, Ulbricht L. Análise da taxa de utilização e perda de vacinas no programa nacional de imunização. Cad Saúde Coletiva. 2013;21(4):420-4. http://dx.doi.org/10.1590/S1414-462X2013000400010

8. Gomes RNS, Portela NLC, Pedrosa AO, Cunha JDS, Monte LRS, Santos CNC. Avaliação físico-funcional de salas de vacinas da rede pública municipal de Caxias-MA. Rev Pesqui Cuid Fundam. 2016;8(1):3793-3802.

9. Marinelli NP, Carvalho KM, Araújo TME. Conhecimento dos profissionais de enfermagem em sala de vacina: Análise da produção científica. Rev Univap. 2015;21(38):26-35

http://dx.doi.org/10.18066/revistaunivap.v21i38.324

10. Santos JAS, Torres DB, Melo RA, Fernandes FECV, Campos MEAL. Fatores determinantes das perdas das vacinas em Unidades Básicas de Saúde. Rev Multidisc Psicol. 2016;10(32):41-53. https://doi.org/10.14295/idonline.v10i32.572

11. Araújo ACM, Guimarães MJB, Frias PG, Correia JB. Avaliação das salas de vacinação do Estado de Pernambuco no ano de 2011. Epidemiol Serv Saúde. 2013;22(2):255-64. http://dx.doi.org/10.5123/S1679-49742013000200007

12. Malachias I, Leles FAG, Pinto MAS, Andrade LCF, Alencar FB, Silva $A E$, et al. Plano Diretor de Regionalização da Saúde de
Minas Gerais (PDR/MG). Adscrição e população dos municípios por microrregião e macrorregião de saúde. Belo Horizonte: Secretaria de Estado de Saúde de Minas Gerais, 2010; p114-73.

13. Brito MFP, Gerin L, Couto ECA, Cunha IS, Corsini MCMM, Gonçalves MC. Caracterização das notificações de procedimentos inadequados na administração de imunobiológicos em Ribeirão Preto, São Paulo, 2007-2012. Epidemiol Serv Saúde. 2014;23(1):33-44.

http://dx.doi.org/10.5123/S1679-49742014000100004

14. Ferreira AV, Freitas PHB, Viegas SMF, Oliveira VC. Acesso à sala de vacinas da Estratégia Saúde da Família: aspectos organizacionais. Rev Enferm UFPE. 2017;11(10):3869-77. http://dx.doi.org/10.5205/reuol.12834-30982-1-SM.1110201722

15. Oliveira VC, Rennó HMS, Santos YR, Rabelo AFG, Gallardo MPS, Pinto IC. Educação para o trabalho em sala de vacina: percepção dos profissionais de Enfermagem. Rev Enferm Centro Oeste Mineiro. 2016;6(3):2331-41. http://dx.doi.org/10.19175/recom.v6i3.1180

16. Hibbs BF, Miller E, Shi J, Smith K, Lewis P, Shimabukuro TT. Safety of vaccines that have been kept outside of recommended temperatures: Reports to the Vaccine Adverse Event Reporting System (VAERS), 2008-2012. Vaccine. 2018;36(4):553-8. http://doi.org/10.1016/j.vaccine.2017.11.083

17. Oliveira VC, Gallardo MDPS, Arcêncio RA, Gontijo TL, Pinto IC Avaliação da qualidade de conservação de vacinas na Atenção Primária à Saúde. Ciênc Saúde Coletiva. 2014;19(9):3889-98. http://dx.doi.org/10.1590/1413-81232014199.12252013

18. Brasil. Ministério da Saúde. Secretaria de Vigilância em Saúde. Departamento de Vigilância das Doenças Transmissíveis. Manual de rede de frio. Brasília: Ministério da Saúde, 2013.

19. Centers For Disease Control And Prevention National Center For Immunization And Respiratory Diseases. Vaccine storage \& handling toolkit. CDC, 2012.

20. Luna GLM, Vieira LJES, Souza PF, Lira SVG, Moreira DP, Pereira AS. Aspectos relacionados à administração e conservação de vacinas em centros de saúde no Nordeste do Brasil. Ciênc Saúde Coletiva. 2011;16(2):513-21. http://dx.doi.org/10.1590/S1413-81232011000200014

21. Long AJ, Hayney MS. Best practices essential for storage and temperature monitoring of refrigerated vaccines. J Am Pharm Assoc. 2013;53(6):660-1. http://doi.org/10.1331/JAPhA.2013.13537

22. McColloster P, Vallbona C. Graphic-output temperature data loggers for monitoring vaccine refrigeration: implications for pertussis. Am J Public Health. 2011;101(1):46-7. http://doi.org/10.2105/AJPH.2009.179853

23. Ribeiro DO, Castro F, Ferreira GC, Santos JC, Coutinho RMC. Qualidade da conservação e armazenamento dos imunobiológicos da rede básica do Distrito Sul de Campinas. J Heal Sci Inst. 2010;28(1):21-8. 